\title{
EXPLANATORY STRATEGIES AS TOOLS EMPLOYED TO COMMUNICATE LEGAL KNOWLEDGE TO A LAY AUDIENCE IN THE JUDICIAL SETTING
}

Olga A. Boginskaya, Department of Foreign Languages, Irkutsk National Research Technical University, koa1504@mail.ru

DOI: 10.31902/fll.35.2021.15

\begin{abstract}
The article analyses the role of explanatory strategies employed to communicate legal knowledge to a lay audience in the judicial setting where the communicants are often asymmetrical. In a jury trial, the important role of the addressee makes it obligatory to identify discursive strategies that improve the interaction of professional and lay courtroom participants. The focus on the laypersons, their phenomenological experience and knowledge makes courtroom discourse dialogical, and intensifies its interactive characteristics. Clarity of courtroom discourse depends on the ability of a speaker to switch from the professional code to lay language, explain legal terms through lay concepts, recontextualize legal knowledge using a series of discursive tools.
\end{abstract}

Key words: audience, courtroom discourse practices, lay audience, asymmetry of knowledge, terminology

\section{Introduction}

When trying to persuade someone, one should always see the one whom you persuade, know his mind and heart, rules by which he is guided (Pascal 1997). Along with the speaker and the subject, the audience is a key element of speech (Aristotle 1987).

The theory of speech acts, sociolinguistics, cognitive linguistics, and argumentation studies have contributed to the studies of an audience as a discursive factor (Chafe 1982; Stolnayker 1985; Perelman 1969; Arutyunova 1982; Clark and Carlson 1986; Heffer 2005 et al.). However, this factor in asymmetric jury trial interactions has been barely studied. Detailed study of legal-lay interactions in terms of discursive strategies employed to improve the comprehensibility of legal texts to a lay audience $^{1}$ is required.

\footnotetext{
${ }^{1}$ The term "lay audience" refers to all non-professional participants in a jury trial, including jury members.
} 
This article aims to identify and describe discursive strategies employed by legal professionals in a jury trial which involves asymmetrical social situations, interactions between experts and laypersons. Explanatory strategies are employed to communicate professional knowledge to a lay audience. Considering the crucial role that these strategies assume in legal-lay interactions, the main research questions addressed here may be reduced to the following:

1) What is knowledge asymmetry in a jury trial?

2) Do legal professionals employ explanatory strategies to communicate legal knowledge to a lay audience?

3) If they do, what types of explanatory strategies are most frequently used by legal professionals?

The paper is structured in the following way. In section 2, the methods employed to analyze the explanatory strategies will be shown and the corpus, including the corpus selection criteria, will be described. The role of knowledge asymmetry in jury trials will be developed in Section 3. Section 4 will demonstrate the types of discursive strategies used to eliminate knowledge asymmetry in jury trials. Finally, in Section 5 , conclusions will be drawn and avenues for further research will be outlined.

\section{Corpus design and research methods}

The research focuses on jury instructions, witness examinations, and closing arguments. A corpus was designed for the purpose of the study following the principles of Corpus Linguistics. Since the texts collected were used as a repository of data, the approach employed in the present research to answer the research questions is corpus-based. The corpus includes 16 closing arguments, 23 witness examinations, and 15 jury instructions retrieved from the website famous-trials.com and the videohosting youtube.com.

To compile the corpus for this study, the texts were selected based on the following criteria:

1) presence of explanatory strategies: the texts were required to contain definitions, descriptions, examples, and metaphors;

2) time: all texts date back to the period between January 2010 and July 2020 as the aim is to focus on synchronically comparable texts.

The texts that met these criteria were shortlisted and selected to build the corpus. The main focus was on the explanatory strategies used and their frequency. The corpus built provides authentic examples to explore how explanatory strategies may be used to eliminate knowledge asymmetry in legal-lay interactions in jury trials. 
The number of texts was 54 . This compilation can be called a smallscale corpus. However, according to Flowerdew (2004), the small-sized corpora provide relevant contextual information, which makes them useful for a context-based analysis.

This corpus-based study aims to describe the discursive strategies employed by lawyers to communicate legal knowledge to a lay audience in jury trials. To comply with this aim, the study employed both quantitative and qualitative analyses. In order to go beyond a mere list of explanatory strategies typically employed in jury trials, the present study applied the interpretative method. According to Creswell (2012), the qualitative research is a good way to address a research problem in which you do not know the variables and need to explore. It does not use statistical data concerning the quality of data. In the present study, the qualitative research is used to analyze and describe the types of knowledge asymmetry-eliminating strategies.

The combination of the qualitative and quantitative methods can contribute to far richer and more explanatory findings. For the purpose of a quantitative analysis, the flexible and easy-to-use statistical data analysis tool - QDA Miner - was used. It can quickly extract and analyze information from large amounts of documents. The quantitative analysis identified the frequency of explanatory strategies used in the corpus. The data on the frequency of explanatory strategies, verbs introducing definitions, types of examples and descriptions were summarized in a diagram format.

\section{Knowledge asymmetry in jury trials}

In jury trials, there are two groups of participants: 1) legal professionals (prosecutors, defense attorneys and judges), and 2) lay people (jury members, witnesses, victims, and defendants) who temporarily enter the courtroom.

It can be assumed that in jury trials, one participant in a communicative event has relevant legal knowledge whereas the other lack it (Krapivkina 2017, 2019). The speaker and the addressee use different types of knowledge (professional knowledge vs. everyday knowledge) which gives rise to a complex dialogue based on the subjective reconstruction of the phenomenological experience, on the one hand, and logical principles and legal rules, on the other hand. Lawyers enter the courtroom with expert knowledge, while jurors - with individual experience and common sense. The ultimate goal of their interaction is to create a shared context of interpretation. Lawyers have been taught to follow the 'paradigmatic' legal principles and procedures, and are well aware of the contribution an evidential point 
might make to their logic-based legal case. At the same time, they are equally well aware of the need to communicate with and persuade a group of lay people (jury members) who are unlikely to reason in a paradigmatic fashion with respect to the evidence detailing the crime narrative at the heart of the case (Heffer 2005). The communicative asymmetry creates a discursive tension which is manifested in macrolinguistic structures of the courtroom genres and microlinguistic choices of the lawyers. Professional training contributes to the mutual understanding between the members of the same discourse community. However, lay participants will inevitably not have the same training and understanding. Metaphorically, lawyers come into law before they come into court which affects the way they view courtroom proceedings (Heffer 2005). The lay participants, on the other hand, come into court without legal training. The professional members understand goal orientations and special constraints, while the lay participants will often not do so.

Jury members come into court as expert triers of fact rather than experts in law. Yet the grounds for their decisions are expertise or known by experience, their experience of everyday life. Bruner (1991) reformulated it as a folk psychology - a sense of the world which is common to the community, 'a system by which people organize their experience in, knowledge about, and transactions with the social world'. In most cultures, the 'organizing principle' of this folk psychology is narrative in nature: "Folk psychology is about human agents doing things on the basis of their beliefs and desires, striving for goals, meeting obstacles which they best or which best them, all of this extended over time" (IBruner, 1991: 25). Thus, jury members bring common-sense and lay experience rather than legal expertise into the courtroom. In other words, they use a narrative rather than a paradigmatic mode of thinking which should be taken into account by legal professionals.

The jury is holding a disadvantageous position derived from a lack of special legal knowledge which is made verbally explicit during the trial. Knowledge asymmetry predetermines the dialectical coexistence of various forms of discursive interactions. While preserving their expert status, legal professionals are forced to employ discursive strategies in order to facilitate comprehension on the part of the jury members. This fact determines the hybrid nature of courtroom discourse. A profile of the addressee is one of the crucial elements of effective communication.

The need for accounting the addressee makes courtroom discourse dialogical, intensifies its interactive characteristics. From this perspective, legal professionals should create a new type of discourse which is different from the expert one, produce new meanings of legal 
concepts which can be comprehensible to the lay participants. To this end, legal professionals use a set of strategies reframing legal concepts for a lay audience.

\section{Types of discursive strategies in legal-lay interactions}

Analysis of the corpus identified four most common discursive strategies employed by lawyers in jury trials to communicate legal knowledge to a lay audience: definition, description, exemplification, and metaphorization.

\subsection{Definition}

In jury trials, definition as a unique logical and discursive strategy involving the interaction of language and thinking plays a significant role in explaining abstract legal concepts to the lay audience. It is used to form a shared context of interpretation by communicating expert knowledge using comprehensible terms.

An analysis showed that definitions are often employed by judges in jury instructions (56 occurrences in the corpus). To make instructions comprehensible to jury members, the judge explains abstract legal categories using lay concepts. Legal concepts that form the expert community framework may be unfamiliar to the jury or have other meanings in General English (murder, intent, negligence, bribe, aggravation, mitigation, burglary, assault, etc.). The same word may have different meanings that serve different semantic purposes which requires explanations of these meanings through definitions. The following example illustrates the case:

(1) "Dangerous weapon" is any weapon that, taking into account the manner in which it is used, is likely to produce death or great bodily harm (Jury instruction).

The judge explains the meaning of the concept dangerous weapon. The definition has a semantic structure.

To "actually possess" a firearm means that George Zimmerman (a) carried a firearm on his person; or (b) had a firearm within immediate physical reach with ready access with the intent to use the firearm during the commission of the crime (Jury instruction).

The judge defines the concept actually possess by including actions which make the content of this concept. As is seen from the example, the structure of this definition is more complex. It is composed of two clauses connected with the conjunction or.

As analysis of the corpus showed that the most common legal terms which are explained by legal professionals are proof beyond reasonable doubt (14 occurrences), negligence (9 occurrences), pledge (5occurrences), 
preponderance of evidence (5 occurrences), burden of proof (10 occurrences), circumstantial evidence (12 occurrences), presumption of innocence (11 occurrences). For example, the term preponderance of evidence is often considered a synonym of the term reasonable doubt. The following example demonstrates the case:

(2) Proof beyond a reasonable doubt is proof that leaves you with an abiding conviction that the charge is true (Jury instruction).

The analysis has revealed that the most commonly employed structure of definitions is Legal term + Definition. The definitions are introduced by the verbs be, mean, include, and be defined. As shown in Figure 2 , the verb be comprising $37 \%$ of all the verbs found in the corpus, is most commonly used to introduce definitions in the corpus. The least commonly used verbs introducing definitions are to include and to be defined, comprising respectively $11 \%$ and $10 \%$.

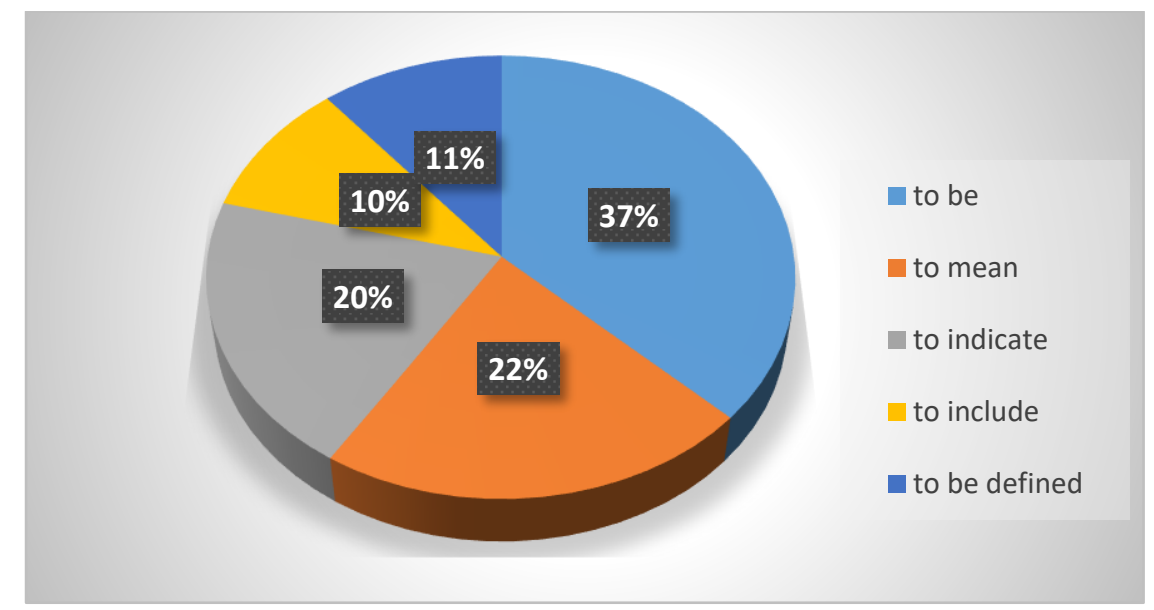

Figure 1. Frequency of the verbs introducing definitions in the corpus

A small amount of definitions found in the corpus (9\%) contain such metalinguistic units as a sort of, a kind of, or like that shows the semantic approximation of the legal term. The following example illustrates this process:

Expert witnesses are like other witnesses, with one exception - the law permits an expert witness to give his or her opinion (Jury instruction).

\subsection{Description}

Along with definitions, legal professionals describe legal terms to make them comprehensible to lay people. They seek to facilitate the comprehension of legal knowledge. The descriptions have simple 
structures and contain information that does not require expert knowledge for its interpretation.

(3) Remember that under the law my client is presumed to be innocent. The prosecution must prove every part of its case beyond a reasonable doubt - that means that you must be very sure. But if you believe the prosecution did not prove any one of these things beyond a reasonable doubt, then you must find the defendant not guilty. Proof beyond a reasonable doubt does not mean beyond all possible doubt. It means that you must consider all of the evidence and that you are very sure that the charge is true (Closing argument).

The addressee is an outsider of the expert legal community; in order to make the information comprehensible to the lay audience, the attorney is forced to describe the meaning of the term reasonable doubt which indicates the intention to eliminate knowledge asymmetry. The similar description is provided by the judge instructing the jury members before the deliberations:

(4) A reasonable doubt is not a mere possible doubt, a speculative, imaginary or forced doubt. Such a doubt must not influence you to return a verdict of not guilty if you have an abiding conviction of guilt. On the other hand if, after carefully considering, comparing and weighing all the evidence, there is not an abiding conviction of guilt, or, if having a conviction, it is one which is not stable but one which wavers and vacillates, then the charge is not proved beyond every reasonable doubt and you must find George Zimmerman not guilty because the doubt is reasonable (Jury instruction).

As is seen from examples (3) and (4), unlike definitions, descriptions contain narrative structures and often extend throughout one or several paragraphs. A corpus-based analysis has shown that definitions are limited to one sentence.

The findings of the present study have revealed the following trends in the length of descriptions found in the corpus (Figure 3). 


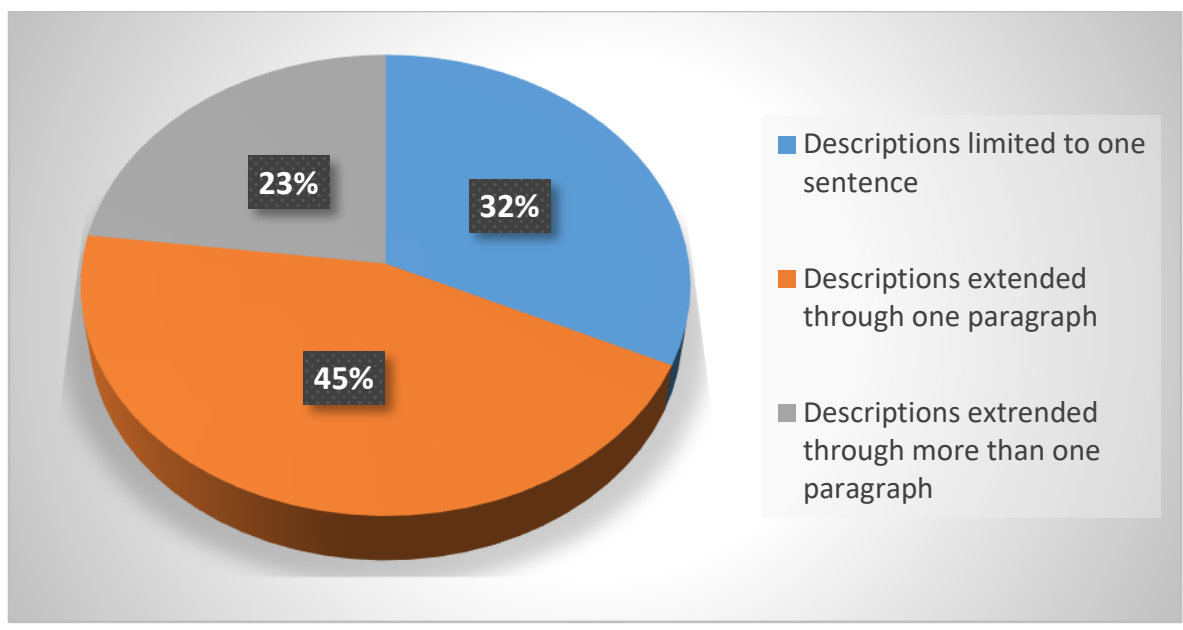

Figure 2. Distribution of descriptions in the corpus by length

An analysis has also revealed four description structures: (a) description + legal term; (b) legal term + description; (c) legal term + description preceded by a definition; and (d) legal term + description followed by an example. Figure 3 shows the distribution of these structures in the corpus.

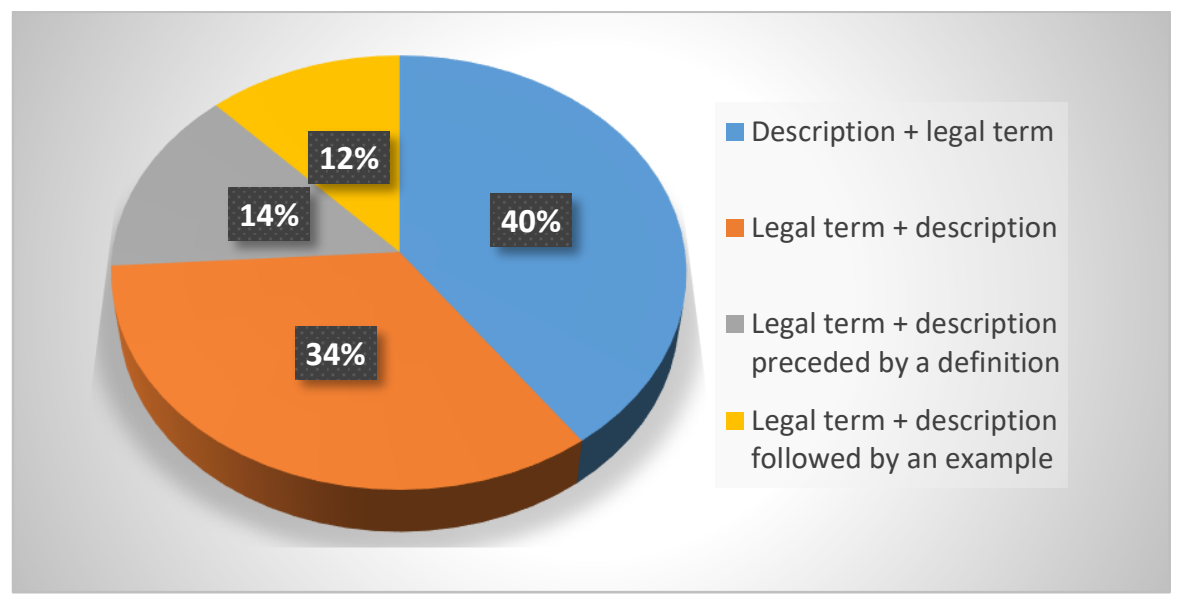

Figure 3. Distribution of description structures in the corpus

It should be noted that in jury trials, asymmetry of knowledge as a communicative obstacle is a characteristic of examination of expert witnesses who often use scientific terms:

(5) Expert: It is a highly vascular area of the neck. lay?

Attorney: When you say 'highly vascular', what does that mean in 
Expert: The term - has got a lot of branches from the arteries and a lot of venous channels, and a wound to this area of the neck, which is one and one-half to two inches deep would cause significant bleeding (Witness examination).

The lawyer interrogates the expert who uses the medical term highly vascular. The lawyer understands that the jury members lack medical knowledge and may incorrectly interpret the statement. Violating the Principle of Cooperation, the expert witness provides less information than the addressee needs (violation of the maxim of quantity); therefore, the lawyer asks him to describe the meaning of the medical term in lay.

\subsection{Exemplification}

Exemplification is based on analogical and case-based processes. Examples allow lawyers to link abstract legal categories to concrete objects of events. The following is an extract from the closing argument. The defense attorney links the criminal law terms direct evidence and circumstantial evidence to concrete images:

(6) Some evidence proves a fact directly, such as testimony of a witness who saw a jet plane flying across the sky. Some evidence proves a fact indirectly, such as testimony of a witness who saw only the white trail that jet planes often leave. This indirect evidence is sometimes referred to as "circumstantial evidence." In either instance, the witness's testimony is evidence that a jet plane flew across the sky (Jury instruction).

Explaining the elusive legal terms by relating them to everyday experience is one of the most effective strategies used in asymmetric interactions. The judge describes the legal terms direct evidence and circumstantial evidence using icon images that can be easily visualized, and phrasing may result in an easily understood representation of the legal terms.

The findings have revealed that legal professionals link legal concepts either to concrete objects or to concrete events or everyday scenarios. The latter exemplification strategy is used to create a possible situation that allows lawyers to explain complex events in a simpler way. The distribution of the types of the exemplification strategy is shown in Figure 4.

Figure 5 presents the most frequent exemplification markers as a percentage of all such markers in the corpus. There seems to be an evident preference for the marker for example, comprising $49 \%$ of all exemplification markers found in the corpus. 


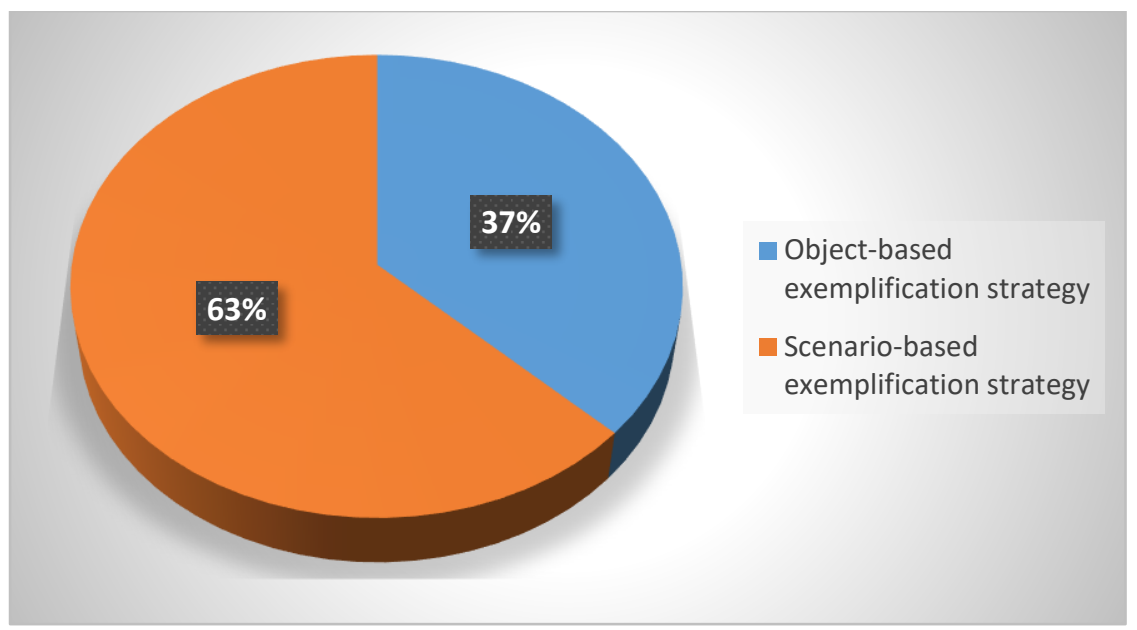

Figure 4. Frequency of the types of the exemplification strategy in the corpus

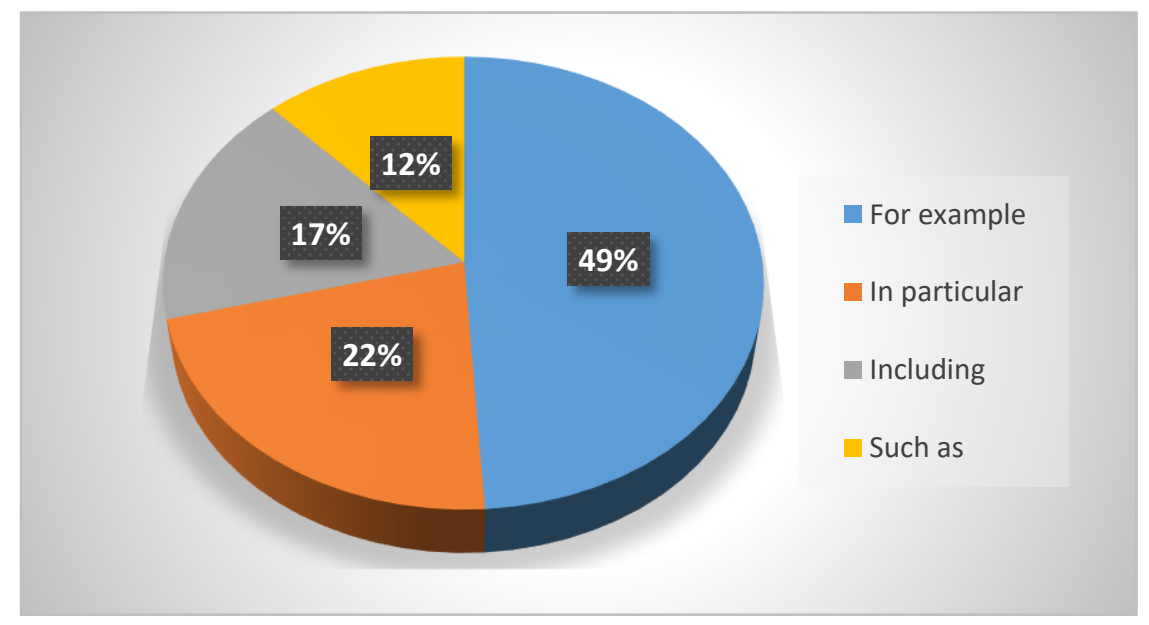

Figure 5. Frequency of the exemplification markers in the corpus

\subsection{Metaphorization}

One more strategy employed to explain abstract legal concepts is metaphorization which offers a series of advantages: terminological transparency, conciseness, and tangible quality of physical images used to represent legal concepts. Metaphor plays a central role in professional language and discourse in the same way it does in general communication. Metaphorical language pervades the specialized discourse of different disciplines including legal sciences (Riejos \& Escribano, 2017: 9). As a result of the metaphorical projection, elements of the source sphere formed during the interaction of a person with the 
world are projected onto the target sphere. Since primary knowledge of the world is physical experience, the speaker categorizes reality as simple images. The following example illustrates the case:

(8) There're too many holes. ... There's too many explanations. They can't put it together. That's the problem. It doesn't come together (Closing argument).

The metaphor too many holes is used to convince the jury members of defendant's innocence. The lawyer metaphorically indicates the absence of irrefutable evidence of client's guilt. The metaphor is employed to explain the abstract legal concept to the jury members. In this example, the use of metaphorical language is one of the ways to bridge the gap between making expert knowledge comprehensible.

(10) And so as we look then at the time line and the importance of this time line, I want you to remember these words. Like the defining moment in this trial, the day Mr. Darden asked Mr. Simpson to try on those gloves and the gloves didn't fit, remember these words; if it doesn't fit, you must acquit (Closing argument).

The metaphor helps the jury members to comprehend the principle of delivering a verdict by non-professional judges: if evidence contradicts facts (does not fit), the defendant has to be acquitted.

The analysis showed that different source domains are required for the recontextualisation of legal concepts (military, sports, technical, household domains).

It is interesting that an analysis has identified metaphors that themselves require the explanation, since the lay audience finds it difficult to comprehend legal concepts they express:

(12) This means that no defendant has any obligation to present any evidence at all, or to prove to you in any way that he is innocent, and this burden stays on the government from start to finish (Jury instruction).

The judge explains the meaning of the legal concept burden of proof. This is a so-called metaphor of law. Unlike metaphors in law, they are legal terms rather than pervasive means.

\section{Discussion and conclusions}

In jury trials, there are two polarized participants: experts and a lay audience. In line with the complexity that is generally associated with the legal field, lay participants are often unable to understand legal information provided by lawyers. The legal concepts can be quite complex, so it may not be realistic to expect perfect comprehension on the part of lay participants. Therefore, legal experts should use a linguistic accommodation towards lay participants in order to facilitate 
comprehension of complex legal concepts. Accommodation towards lay participants is a prerequisite for successful communication, requires a series of discursive strategies, and depends on the ability of lawyers to explain complex legal concepts in a comprehensible, simple way. Analysis of the corpus has shown that the language used in the explanations can be formal at times, and with complex syntactic structures. However, it differs from legalese in that it lacks archaisms, nominalizations, abstract terms or terms with a flexible meaning. It aims not to cause difficulties for average native speakers. A higher level of understanding and awareness helps lay participants, including jury members, better assess legal information and make proper legal decisions.

The better results of understanding legal information that can be obtained through the use of explanatory tools are due both to the more ordinary phrasing of legal utterances and to the fact that lawyers provide a lay audience with examples and metaphors that relate abstract legal terms to everyday experience.

Analysis of the corpus has shown that definitions, descriptions and examples, comprising respectively $36 \%, 29 \%$ and $21 \%$, are the most common strategies employed by legal professionals to communicate legal knowledge to the lay audience. Metaphors, comprising only $14 \%$ of all strategies used, are the least common tools employed by the lawyers to communicate legal knowledge. This may suggest that there is a certain potential for vagueness which is inadmissible in the legal setting. The results of the quantitative analysis of discursive strategies employed by lawyers in jury trials is presented in Figure 6 .

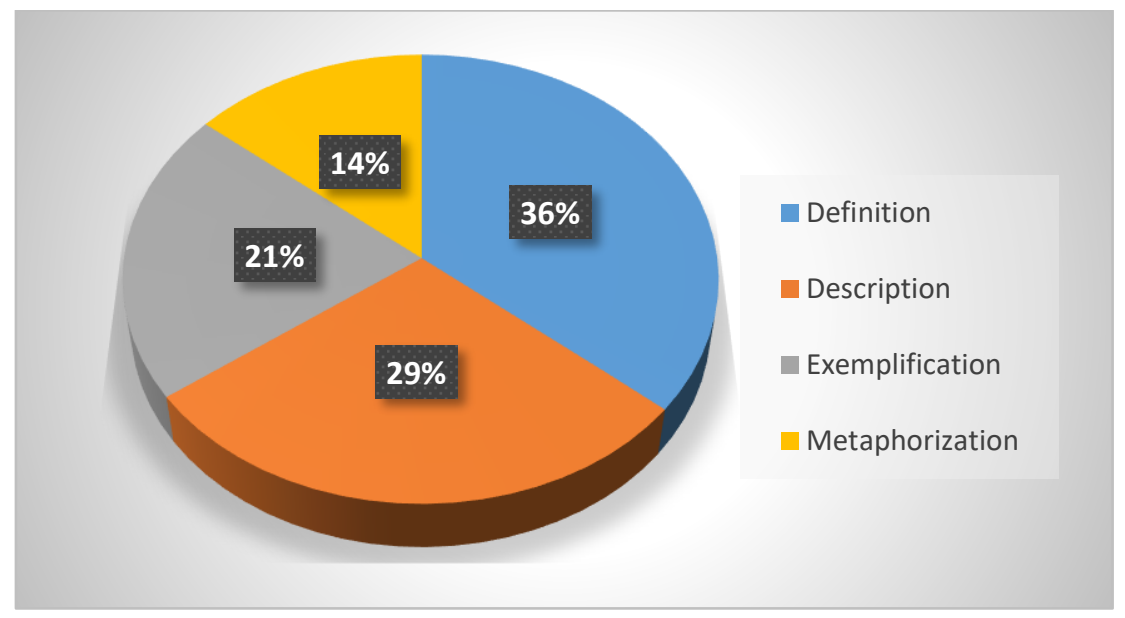

Figure 6. Discursive strategies employed by lawyers in a jury trial 
The present study has revealed that strategies employed by legal professionals with the aim of explaining legal knowledge to a lay audience are:

(1) definitions explaining legal terms in a paradigmatic manner;

(2) descriptions employed to mediate new knowledge by relating it to the existing one in a narrative way;

(3) examples used to avoid communication problems by relating legal terms to concrete objects or events;

(4) metaphors that facilitate jurors' comprehension of abstract legal terms by bringing them closer to everyday experience;

The significance of the present study lies in the attempt to describe the discursive strategies intended to improve the comprehensibility of legal terms and overcome communication problems in jury trials. It contributes to knowledge of the ways of accommodating legal information practices towards a lay audience and draws attention to the issues of knowledge asymmetry. 16 closing arguments, 23 witness examinations, and 15 jury instructions were analyzed with the aim of identifying the most common strategies employed to translate legal terms into lay concepts. Since they are basically tools for facilitating access to complex legal information, their function is to aid the lay audience's comprehension. These explanatory tools have specific features that allow us to distinguish between them.

This study on the explanatory strategies employed in jury trials is only a glimpse into asymmetrical interactions in professional settings. I suggest that further studies be undertaken to explore this research area, either by extending the methodology or examining other aspects of expert-lay interactions, including the types of syntactic complexity of legal texts. Paraphrasing experiments could be conducted to prove the efficiency of the explanatory strategies used in the judicial setting. Paraphrase tasks as an efficient tool in the investigation of linguistic and conceptual features of legal discourse can help to assess lay persons' conceptual difficulties.

The research could be extended further by carrying out studies in other professional areas on the materials presented in various languages. Empirical studies on the role of metaphor in professional settings can bring invaluable insights upon professional language and reveal the linguistic vehicles that experts employ.

\section{References:}

Aldridge, M., Luchjenbroers, J. Linguistic manipulations in legal discourse: Framing questions and "smuggling" information. In International Journal of Speech, Language, and Law, 14(1) (2007): 83-105.

Anesa, P. "Now you are getting into the law": mediation of specialised language in a jury trial. In Fachsprache, 1-2 (2009), 64-82. 
Anesa, P. The deconstruction and reconstruction of legal information in expertlay online interaction. In ESP Today, 4(1) (2016): 69-86.

Anesa, P., Kastberg, P. On some communicatively salient complexities of knowledge asymmetries in a jury trial. In Text and Talk, 32(1) (2012): 1-19.

Aristotle. Antique Rhetoric, Moscow: Moscow University Press, 1978.

Aron, R., Fast, J., Klein, R. 1996. Trial Communication Skills, Deerfield: Ill., Clark Boardman Callaghan, 1996.

Arutyunova, N.D. Factor of an addressee. In News of the AS USSR. Literature and language, 40(4) (1981), 356- 367.

Boginskaya, $O$. The simplification of jury instructions: legal-lay interactions. In ESP Today, 8(2) (2020): 297-318.

Bruner, J. The narrative construction of reality. In Inquiry, 18 (1991): 1-21.

Calsamiglia, H., Dijk, T. van. Popularization discourse and knowledge about the genome. In Discourse \& Society, 15(4) (2004): 369-389.

Chafe, W.L. Given, contrast, certainty, subject, topics and point of view. In: New in foreign linguistics, 11 (1982): 277-317.

Clark, G.G., Karlsson, T.B. Listeners and Speech Act. In: New in foreign linguistics: Theory of speech acts, 17 (1986): 270-321.

Cotterill, J. Language and power in court: A linguistic analysis of the 0 . J. Simpson trial, New York, Palgrave MacMillan, 2003.

Creswell, J. W. Educational research: Planning, conducting, and evaluating quantitative and qualitative research. Boston, MA, Pearson, 2012.

Evans, K. The Golden Rules of Advocacy, London, Blackstone Press, 1993.

Felton Rosulek, L. Dueling discourse: The construction of reality in closing arguments, Oxford University Press, 2015.

Flowerdew, L. The argument for using English specialized corpora to understand academic and professional language. In U. Connor and T. A. Upton (Eds.), Discourse in the professions: Perspectives from corpus linguistics. Amsterdam/ Philadelphia, John Benjamins, 2004: 11-33.

Golodnov, A.V. Persuasiveness as a universal strategy of text formation in the rhetorical metadiscourse, Saint Petersburg, SPSU, 2011.

Gotti, M. Investigating Specialized Discourse, Bern, Peter Lang, 2008.

Heffer, C. The language of jury trial, Houndmills, Palgrave, 2005.

Hyland, K. Applying a gloss: Exemplifying and reformulating in academic discourse. In Applied Linguistics, 28(2) (2007): 266-285.

Kastberg, P. Knowledge asymmetries. Beyond "to have and have not". In Fachsprache, 34(3-4) (2011): 137-151.

Krapivkina, O.A. Expert-lay interaction in jury trials (case study of closing arguments). In Journal of Language and Cultural Education, 5(3) (2017): 77-92.

Krapivkina, O.A. Discourse of concord as a result of integration of possible worlds of communicants (case-study of closing arguments). In Voprosy Kognitivnoy Lingvistiki, 2, 2018: 45-50.

Legal dictionary. http://legal-dictionary.thefreedictionary.com

Litvinenko, T.E. Metaphor in religious discourse. In Vestnik of Moscow State Linguistic University, 716 (2015): 79-88. 
Nickerson, R. S. How we know - and sometimes misjudge - what others know: imputing one's own knowledge to others. In Psychological Bulletin, 125 (1999), 737-759.

O'Barr, W. M. Linguistic evidence: Language, power, and strategy in the courtroom, New York, Academic Press, 1982.

Pascal, B. Logic and rhetoric, Minsk, TetraSystems, 1997.

Perelman, C. The New Rhetoric. A Treatise on Argumentation, Notre Dame, University of Notre Dame Press, 1969.

Privalova, I.V., Shaidullina, A.R., Zheltukhina, M.R., Grinberg, T.E., Gaselles, C.G. Coerced loss of national colorings-linguistic issues of virtual team communication. In Xlinguae, 1 (2019): 151-164.

Review of judicial cases (2003). http://www.consultant.ru.

Riejos, A.R., Escribano, P.D. Metaphor in the specialized discourse of scientific disciplines and technology. In Iberica, 34 (2017): 9-16.

Stolnaker, R.S. Pragmatics. In New in foreign linguistics: Linguistic pragmatics, 16 (1985): 419-438.

Turnbull, J. Communicating and recontextualizing legal advice online in English. In Popularization and Knowledge Mediation in the Law. Popularisierung und Wissensvermittlung im Recht. Engberg J., Luttermann K., Cacchiani S., Preite C. (Eds.). Zurich, Lit Verlag, 2018: 201-222).

\section{ЭКСПЛАНАТОРНЫЕ СТРАТЕГИИ КАК ИНСТРУМЕНТЫ ЭФФЕКТИВНОГО ВЗАИМОДЕЙСТВИЯ НОСИТЕЛЕЙ ЭКСПЕРТНОГО И ОБЫДЕННОГО ЗНАНИЯ В СУДЕ ПРИСЯЖНЫХ}

В статье анализируется роль адресата как определяющего фактора производства дискурсивных практик в суде с участием присяжных заседателей. Данный фактор влияет на выбор дискурсивных стратегий и языковых средств оформления дискурса. В судах с участием присяжных заседателей важная роль данного фактора заставляет юристов использовать дискурсивные стратегии, оптимизирующие взаимодействие профессиональных и непрофессиональных участников судебного заседания. Учет фактора адресата, его феноменологического опыта и знаний делает дискурс юристов диалогичным, усиливает его интерактивные характеристики. Анализ стенограмм судебных заседаний помог вывить наиболее распространенные дискурсивные стратегии, используемые юристами для создания общего контекста интерпретации при взаимодействии с непрофессиональными участниками. Переход от юридического языка к естественному делает судебную речь понятной для носителей обыденного знания. Новизна исследования заключается в выборе траектории исследования, основанной на проблеме взаимодействия профессиональных и непрофессиональных участников институциональной коммуникации.

Ключевые слова: аудитория, судебный дискурс, носители обыденного знания, асимметрия знаний, терминология. 